\title{
KAHRAMANMARAŞ ÇOCUK ABALARINDA NAZARLIK
}

\author{
Kahramanmaraş Children's Evil Eye Aba
}

\section{Songül KURU * \& Zeynep KIRKINCIOĞLU**}

Makale Gönderim: 18.03.2016

Kabul Tarihi:

10.05 .2016
Öz: Inanç sistemine bağlı olarak gelişen toplumlarda, sembolik ifadeler, kişisellikten öte, toplumca kabul gören ortak değerleri yansıtmışlardır. Semboller, bir arada yaşayan insanların ortak özelliklerini, inançlarını, göreneklerini temsil ederek ve onların diğerlerinden ayrılmasını sağlamaktadır. Yaşam, doğum, üreme, korunma vb. gibi insanlığın ortak döngüleri üzerine kurgulanan semboller, önceleri mağara duvarlarında ve mitolojilerde yer alırken, daha sonra dokuma ve desenleme tekniklerinin geliştirilmesiyle, bu görevi dokumalar üstlenmiştir. Dokuma ürünlerine uygulanan desenlerle; doğum, bereket, beslenme, ölüm, korunma ile ilgili birçok anlam yüklemiştir. Korunma ile ilgili motiflerin başında nazar, nazarlıklar gelmektedir. Anadolu'da önemli inançlardan birisi de nazar inancıdır. Arapça bakış anlamına gelen nazar, Türkçede de aynı manada kullanilır.

Çalışmanın amacı; Türk kültüründe önemli yeri olan nazar konusu hakkında bilgi vermek ve Kahramanmaraş çocuk abalarında bulunan nazar ve koruma ile ilgili motifler ve süslemeleri fotoğraf ve çizimlerle irdeleyerek değerlendirmektir. Betimsel yöntemin kullanıldığı araştırmada, Anadolu gelenek ve göreneklerine göre çocukları nazardan korumayla ilgili inançlardan bahsedilmiştir. Kahramanmaraş çocuk abalarında geleneksel öğeler içeren nazara karşı koruyucu motifler, çeşitli malzeme ve objelerden yapılan süslemeler ve ifade ettiği sembolik anlamlar yorumlanarak öneriler getirilmiştir.

Anahtar Sözcükler: Kahramanmaraş, nazar, koruma, motif, aba

\footnotetext{
* Yrd. Doç. Dr., Atıım Üniversitesi Güzel Sanatlar Tasarım ve Mimarlık Fakültesi Tekstil ve Moda Tasarımı Bölümü, Ankara. songulkuru@gmail.com/songul.kuru@atilim.edu.tr

** Dr., Atatürk Üniversitesi Güzel Sanatlar Fakültesi Tekstil ve Moda Tasarımı Bölümü, Erzurum. zeynep060@hotmail.com
} 
Abstract: In the societies that develop according to belief system, symbolic expressions reflect socially accepted common values rather than intimateness. Symbols represent common feature, beliefs and traditions of people living together and they ensure a society to be different from another. Symbols that are built on the common cycles of humanity such as life, birth, reproduction, protection etc. had firstly been on the walls of caves and in mythologies; then they were used in weavings with the development of weaving and ornamenting techniques. People have attributed various meanings to the patterns they used on weaving products about birth, reproduction, abundance, nutrition, death and protection. The most significant patterns about protection are evil eye, amulets. One of the important beliefs in Anatolia is the belief of evil eye. Evil eye means "look" in Arabic which is used in the same meaning in Turkish.

Goal of the report is; to give information about the issue of evil eye that is significant in Turkish culture and to evaluate patterns and embellishments about evil eye and protection on Kahramanmaraş children aba by analyzing them with photographs and drawings. In the research, in which descriptive method was used, beliefs about protecting from evil eye according to Anatolian traditions and customs were mentioned. Evil eye protection patterns on Kahramanmaraş children aba that includes traditional elements, ornaments that are made of various materials and objects are interpreted and suggestions are made in the research.

Key Words: Kahramanmaraş, evil eye, protection, pattern, aba 


\section{GİRIŞ}

Dokuma; atkı, çözgü ipliklerinin dikey açı yapacak şekilde, birbirinin altından, üstünden geçirilmesiyle ortaya çıan düz yüzeyli üründür de denilebilir (Ertem, 2009: $35)$.

Aba; yıkanmış, temizlenmiş ve taranmış yün yapağından dokunarak veya dövülüp bastırılarak elde edilen kalın bir kumaş çeşididir. Deve, öküz, keçi kılı veya koyunyünü aba kumaş dokumasında kullanılır. İnce keçeye benzer görünümlü kalın bir dokuma olan aba; soğuğu geçirmeyen özelliği ile genelde iklimi sert ve soğuk yörelerde kullanılmaktadır. Çoğunlukla cübbe, hırka, potur, çakşır, terlik olarak kullanılmakla beraber, Osmanlı döneminde askeri birliklerde de giyim eşyası, tozluk ve dizlik olarak da değerlendirilmiştir (Salman, 2009: 195). Bursa, Gaziantep, Kahramanmaraş'ta dokunmuş değişik örnekleri bulunmaktadır. Genel olarak Kahramanmaraş’ta dokunan ve geçmişten günümüze kadar gelebilen nadide el sanatlarımızdan biri olarak bilinmektedir. Dokuma esnasında yapılan desenleme yöntemiyle oldukça ilgi çekici zarif bir ürün olan aba, yaşatılması ve elde kalan örneklerinin korunması gereken önemli bir yerel üründür.

Kahramanmaraş abası çıkrıkta bükülen ve kökboyası ile boyanan iplerin ahşap tezgâhlarda ustanın maharetiyle desen oluşturularak dokunan bir kumaştır. Aba, gömme tezgâh (çukur tezgâh) dediğimiz yer seviyesinden biraz daha aşağıda kurulan tezgâhlarda dokunmaktadır (Salman ve Mercimek, 2012: 412). Dokunan abalarnn ipleri ise deve, öküz, keçi, kuzu yünlerinin orijinal renklerinin korunumuyla veya yün yapağının dövülüp bastırılmasıyla elde edilen iplerin doğal boyama yöntemi ile boyanmış eğrilmiş, bükülmüş iplerdir. Renkli işlemeli abalarda kullanılan ipler kök boya ile renklendirilmiştir. Ayrıca kişinin ekonomik ve sosyal durumuna göre dokunan abanın malzemesinde çeşitlilik artmaktadır. Yani kullanılan iplere ilaveten gümüş ve altın suyuna batırılmış sırmalar ve ipek ipler kullanılmaktadır. Sim sırma ve gümüş sırma ile dokunan abalar kişinin ekonomik ve sosyal durumu ile bilgi sahibi olmamıza olanak sağlar.

Aba parçalar halinde dokunduktan sonra tezgâhtan çıkarılıp şekil verilerek birleştirilen bir dokumadır. Aba iki parçadan meydana gelmektedir. Abayı oluşturan parçalar ise alt şah ve üst şah olarak adlandırılmaktadır. Alt şah alt bölüm, üst şah ise üst bölüm demektir. Aba dokunduğu ipin çeşidi ve rengine, üzerindeki motife, boy ölçüsüne, giyildiği yöreye ve giyen kişinin özelliklerine göre isimlendirilir ve çeşitlilik gösterir. Aba çeşitlerine şunlar örnek olarak verilebilir. Suriye (Humus) abası, yerli aba (kırmızı, siyah, lacivert ve toprak renginde), sırmalı aba, kısa aba, kıl aba, uzun aba gibi (Salman ve Mercimek, 2012: 412).

İnanç, bir kimsenin günlük yaşamını, davranışlarını etkileyen, başkalarından 
öğrenme yoluyla kazanılan düşünce varlığıdır. İnanç denemeden, us kurallarına ve mantık ilkelerine uygunluğu olmadan benimsenen, genel geçerliliğini yalnızca başkalarından aktarılan olaylara, söylentilere dayalı olan bir düşünce ürünüdür. Anadolu inançları da Anadolu'da yaşayan halkın yaşamıyla, tarihiyle ve kültürel özellikleri ile yakından ilgilidir (Etikan ve Kıliçarslan, 2012: 105).

İnanç sistemine bağlı olarak gelişen ilkel sembolizmde, sembolik ifadeler kişisellikten öte, toplumca kabul gören ortak değerleri taşımışlardır. Semboller, bir arada yaşayan insanların ortak özelliğini, inançlarını, göreneklerini temsil etmekte ve onların diğerlerinden ayrılmasını sağlamaktadır. Varoluş, yaşam, doğum, koruma, üreme vb. gibi insanlığın ortak döngüleri üzerine kurgulanan semboller, önceleri bu döngüler üzerine edinilen bilgileri mağara duvarlarında ve mitolojilerde gelecek kuşaklara taşıma görevi yüklenmişlerdi. Daha sonra dokumanın keşfedilmesi ve onu desenleme tekniklerinin geliştirilmesiyle, bu görevi dokumalar üstlenmiştir (Yıldırım, 2006: 371). İnsanlar inançlarını, duygu ve düşüncelerini dokumalarla, desenler ile anlatmaya başlamışlardır. Dokumları tek renk, düz olarak değil, çeşitli renkler, desenler, ifadeler vererek dokumuşlardır. Dokuma desenlerini çevrelerinde gördükleri figürler, hayal ettikleri olaylar, doğaüstü şekillerden esinlenerek oluşturmuşlardır. Dokuma ürünlerinin üzerine uyguladıkları desenlere ve motiflere; doğum, çoğalma, ölüm ve korunma (nazar) ile ilgili anlamlar katmışlardır. Korunma ile ilgili motiflerin başında, göz, muska, nazarlık motifleri gelir. Ayrıca; pıtrak, el, parmak, tarak, haç, çengel, yılan, akrep, kurtağzı, hayat ağacı motifleri de korunma ile ilgili motiflerdendir (Öztürk, 2005: 130).

Çok eski dönemlerden beri var olan halk inanışlarından biriside, korunma inancı olan nazar inancıdır. Nazar kelimesinin aslı Arapçadır. Kelime Türkçeye asıl anlamından biraz uzaklaşarak geçmiştir. Araplar bizim kullandığımız anlamdaki nazar kelimesi karşılı̆̆ında "İsabet’ülayn” tabirini kullanmaktadırlar. Türkçede ise sözlük anlamı olarak bakma, bakış, göz atma, düşünce olan kelime, halk inançları dolayısıyla halk söyleyişi içinde göz değmesi, göze gelme anlamında kullanılmaktadır. Nazar kelimesi göz değmesi karşıllı̆ı olarak, nazar değmesi, nazara gelme, nefesi dokunma, kem göz, kem nazar şeklinde de kullanılmaktadır (Ertem, 2009: 1).

Bütün toplumlarda yaygın olarak görülen nazar inancının kökeni, Neolitik çağlara kadar uzanmaktadır. Girit’te, Aşağı Mısır'da, Malta'da, Kuzey Fransa'da ve Britanya'da Bronz çağına ait, balta şeklinde yapılmış nazarlıklar (amuletler) bulunmuştur. Araştırmalar sonucunda, eski dönemlerden itibaren Batı'da ve Doğu'da büyünün ve nazarın kötü etkilerine inanma ve bunlara karşı tedbirler alma bilgisinin köklü olduğu görülmüştür. Aynı şekilde uğursuz gözlerden gelen fenalığı ortadan kaldırmak için Mısırlılar, Fenikeliler, Yunanlılar ve Romalılar tarafından el şeklindeki muskaların kullanıldığı tespit edilmiştir. Geçmişten günümüze varlığını sürdüren bu inanış, ülkemizin hemen her köşesinde günlük hayatın içerisinde ve bütün etkinliğiyle varlığını devam ettiren, geçerliliğini koruyan bir folklorik uygulamadır (Çıblak, 2004: 103). Kahramanmaraş çocuk abalarında kullanılan nazarlıklar, motifler, semboller ve 
objeler de bunun en güzel örnekleri içinde yer almaktadır.

\section{MATERYAL VE YÖNTEM}

Materyalini Kahramanmaraş yöresinde ulaşılan çocuk abası örneklerinin oluşturduğu betimsel araştırmada; 2012 Ekim ayında yöreye gidilerek alan araştırması yapılmıştır. Kahramanmaraş Müze Müdürlüğü, Halk Eğitim Merkezi, Yaşar Pastanesi çalışanları ve Kahramanmaraş halkı ile görüşmeler yapılmış, aba hakkında bilgi edinilmiştir. Abaların orijinal hali ile müzelerde ve özel koleksiyonlarda saklandığı belirlenmiştir.

Araştırmada; Kahramanmaraş Yaşar Pastanesi sahibi Mehmet Kambur'a ait özel koleksiyonda yer alan 2 adet çocuk abalarında, geleneksel öğeler içeren nazara karşı koruyucu motifler, çeşitli malzeme ve objelerden yapılan süslemeler ve ifade ettiği sembolik anlamlar üzerinde durulmuş, fotoğraflanmış, motiflerin çizimleri yapılmış, yorumlanarak sonuca gidilmiştir.

\section{BULGULAR}

Anadolu'da her çeşit canlı cansız varlıklar üzerinde ciddi etkileri olduğuna inanılan nazarın, özellikle insan yaşamının geçiş dönemlerinde ayrı bir önemi olduğu bilinmektedir. Özellikle geçiş dönemlerinin ilki olan doğum evresinde bebeklerin büyük tehlike altında olduğu düşünülmektedir. Anne ve babalar bu çarpıcı tehlikeden bebeklerini korumak için birçok yola başvururlar. Bundandır ki bebeklere göz boncukları, maşallahların takılması, bebeğin kırkı çıkana kadar dışarı çıkarılmaması ve özellikle bu dönemde misafirden çekinilmesi, bebeği severken güzel ifadeler yerine "çirkin" gibi yakıştırmalar yapılması, okunup üflenmesi, kırklama merasiminin yapılması gibi birçok uygulamanın görülmesidir (Öcalan, 2010: 14).

Anadolu'nun genelinde olduğu gibi Kahramanmaraş yöresinde de nazar inancı oldukça yaygındır. İnançla ilgili çeşitli korunma yöntemleri ile birlikte nazara karşı koruyucu kolonlar (çarpana dokuma), kordonlar ve benzeri dokumalarda yapmışlardır. Kahramanmaraş'ta farklı dikdörtgen, üçgen ve benzeri formlardaki dokumalar ve kolonlar ile objeler çocuk abalarının üzerinde nazara karşı koruyucu en çok kullanılan süslemeler olmuştur. Çalışmanın bu bölümünde, Kahramanmaraş Yaşar Pastanesi sahibi Mehmet Kambur'un Özel Koleksiyonunda yer alan çocuk abalarının üstündeki dokuma nazarlıklar ve nazarlıkların üzerinde yer alan nazar motifleri, objeler ve ifade ettiği sembolik anlamları incelenmiştir. 

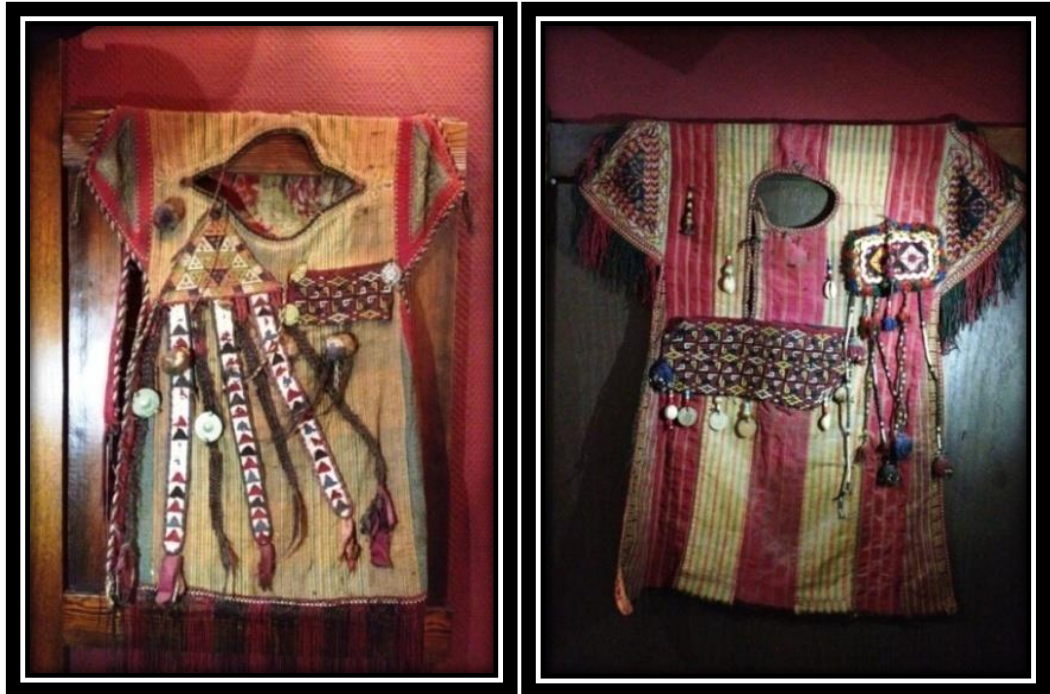

Resim 1

$\operatorname{Resim} 2$

Çocuk Abaları (Z. Kırkıncıoğlu \& S. Kuru)

(Mehmet Kambur Özel Koleksiyonu, Yaşar Pastanesi Kahramanmaraş, 2012)

Resim 1 ve 2'de Kahramanmaraş çocuk abalarının süslemelerinde, çok çeşitli obje ve malzemelerin kullanıldığı görülmektedir. Bu malzemeler arasında tahta ve cam boncuk, tazı boncuğu, deniz kabuğu, para, penez, metal, iplik, saç örgüsü kolonlar, nazar motifli farklı dokumalar, sutaşı vb. malzemeler yer almaktadır.

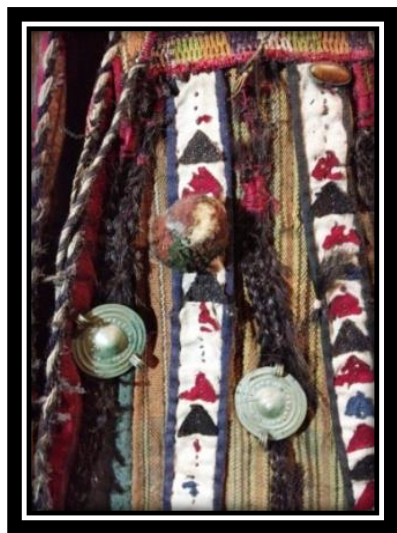

Resim 1a

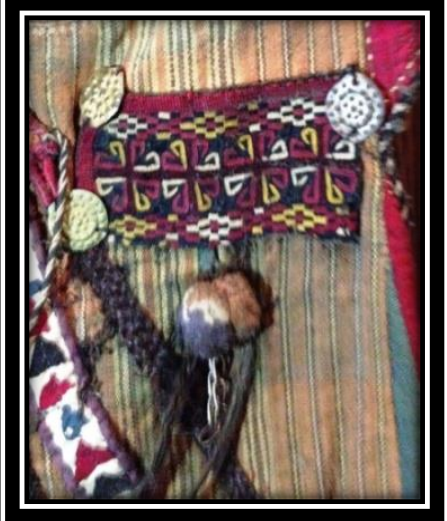

Resim 1b 


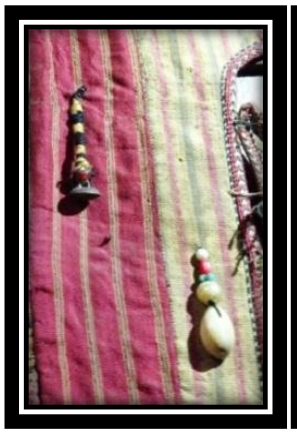

$\operatorname{Resim} 2 \mathrm{a}$

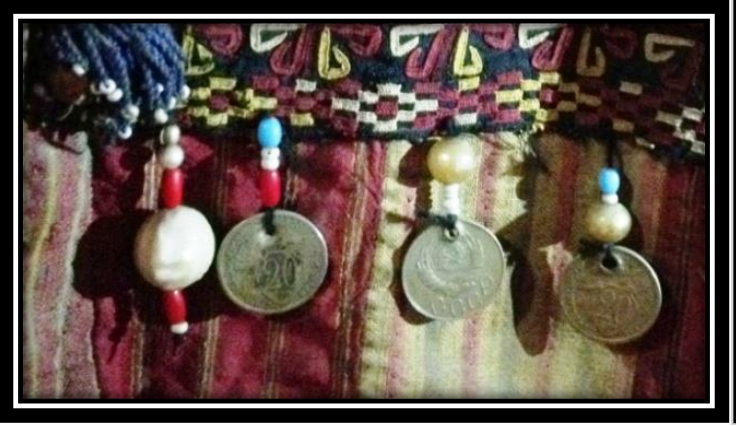

$\operatorname{Resim} 2 b$

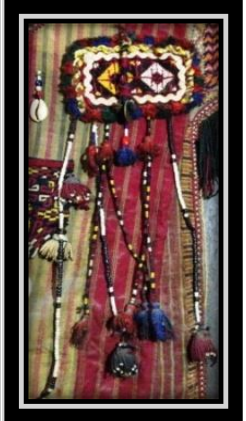

Resim 2c

Çocuk Abası Detayları (Z. Kırkıncıoğlu \& S. Kuru)

Nazardan korunmak için alınan önlemlerin en başında nazarlıklar gelir. Halk inancına göre, onu üzerinde taşıyanı büyüye, hastalıklara ve diğer kötülüklere karşı korumaya veya içinde bulunduğu durumdan kurtarmaya hizmet eden objeye nazarlık denilmektedir (Koşay, 1956: 86).

Nazarlıkların temel anlamı koruma ve korunmaya yönelik olup, bu objelerin sadece biçimleri değil, yapıldıkları malzemeler ve renkleri de önemlidir. Çünkü bu malzemelerin özünde gizli kuvvet taşıyan niteliklerin olması gerekmektedir. Tabiattaki objelerin parlaklık, zenginlik, kuvvet gibi nitelikleri karşısında şaşıran ve korkan insan, felaketlerin ve mutluluğun bu objelerin içinde olduğunu sanarak bu objelerle barışık olmak istemiş ve onları kendi hizmetinde kullanmayı düşünmüştür (Üçer, 1997: 165).

Nazarlık taşıma geleneği Maraş yöresinde çok yaygındır. Genellikle omuza takılan nazarlıkların başlıcaları şunlardır; Mavi boncuk, yedi delikli boncuk, hurma çekirdeği, kurt boncuğu, kurt gözü, sarı kehribar, yılan kemiği veya kabuğu, küçük mavi boncuktan yapılmış kertenkele, küçük mavi boncuktan örülmüş el şekli, göz boncuğu, at nalı, eski süpürge, yumurta kabuğu, üzerlik, karanfil, eşek nalı, kara boncuk, kesilmiş para, balık kulağı, kendiliğinden delikli taş v.b. nazarlık olarak kullanılmıştır (Erberk, 2002: 124). Resim 1 ve 2‘de görüldüğü üzere Maraş çocuk abalarında da nazardan korunmak için eski para, mavi boncuk, deniz hayvanı kabuğu, sutaşı, iplik, renkli boncuklar, küçük kumaş parçaları ve kolan dokumalar daha çok kullanılanlar arasındadır. Ayrıca metal nazarlıklarda; altın, gümüş gibi metaller kullanılmıştır. Anadolu kültüründe altın ve gümüş temizliğin sembolüdürler (Koşay, 1956: 87).

Resim 3 'te Maraş abasının sağ yakasına takılan nazarlık, korunma motiflerinden olan muska ile sembolize edilmektedir. Muska, eşkenar üçgen, ikizkenar üçgen ve bazı 
alanlarda ise, kare, dikdörtgen, silindir şeklindeki geometrik form olarak nazardan korunmak için kullanılmaktadır.

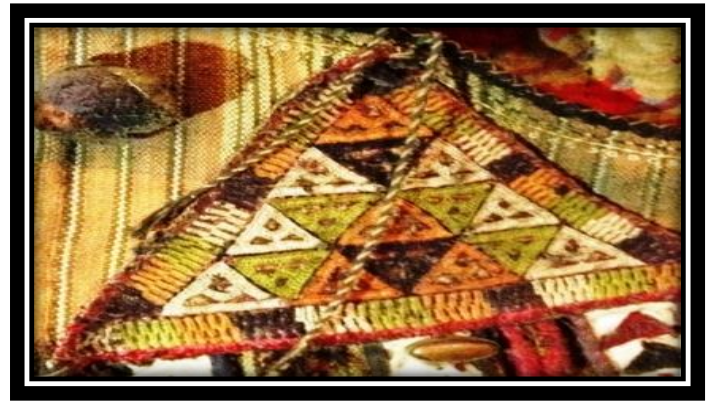

Resim 3: Resim 1'deki Çocuk Abası Detayları (Sağ Yaka) Üçgen Nazarlık Dokuma

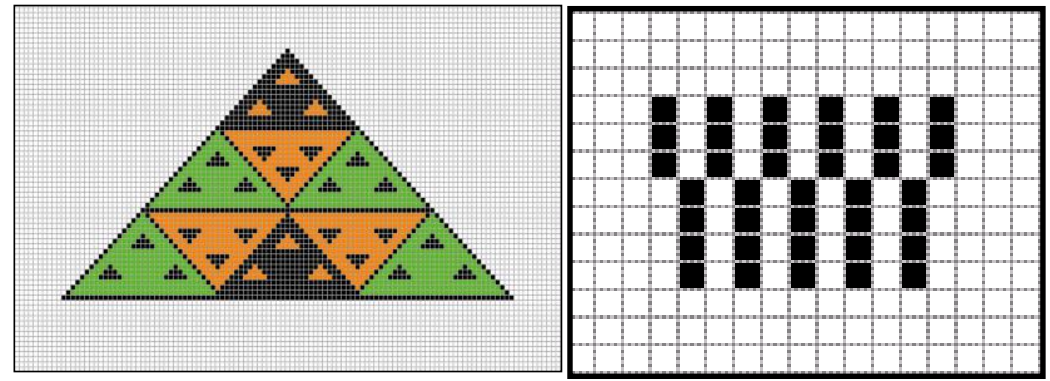

Çizim 1. Nazarlık Dokuma Motifi Çizim 2. Nazarlık Dokuma Deseni

Çizim: Z. Kırkıncığlu

Parmak ve ona çok benzeyen tarak motifleri, geometrik olarak üçlü, beşli, yedili ve katların sayıları kullanılarak dokunmuştur. Bir gövdeye bağlanan çeşitli çubuk formlarından oluşur ve duruma göre el parmak veya tarak isimlerini alır (Erberk; 2002: 114) (Resim 3).

Resim 3 'te Maraş abasının sağ yakasına takılan nazarlık, korunma motiflerinden olan muska ile sembolize edilmektedir. Muska, eşkenar üçgen, ikizkenar üçgen ve bazı alanlarda ise, kare, dikdörtgen, silindir şeklindeki geometrik formlarda yapılarak nazardan korunmak için kullanılmaktadır. Muskanın alt kısmından aşağıya üç tane kolon dokuma sarkmaktadır. Kolanlar malzemesi iplik olan; bazen dokunmuş, bazen de elde örülmüş ip, bağ, kemer, kuşak, kulp olarak da ifade edilen dar dokuma ürünlerdir (Atlıhan, 2012: 131). Resim 4'teki kolonlar çarpana dokuma tekniği ile dokunmuştur. Dokumaların üzerine üç renkte üçgen geometrik desen yapılarak uçlarına kumaş parçası 
geçirilmiştir. Kolon dokumaların arasına saç örgüsü kolonlar eklenmiştir (Resim 4). Örgülü Kolanlar tezgâh kullanılmadan, farklı sayıda çözgü gruplarının bir düzen içinde birbiri içinden geçirilmesi ile bir anlamda parmaklarla dokunan ve adına "örgü” ya da "örme" denilen kolanlardır (Atlihan, 2012: 131).

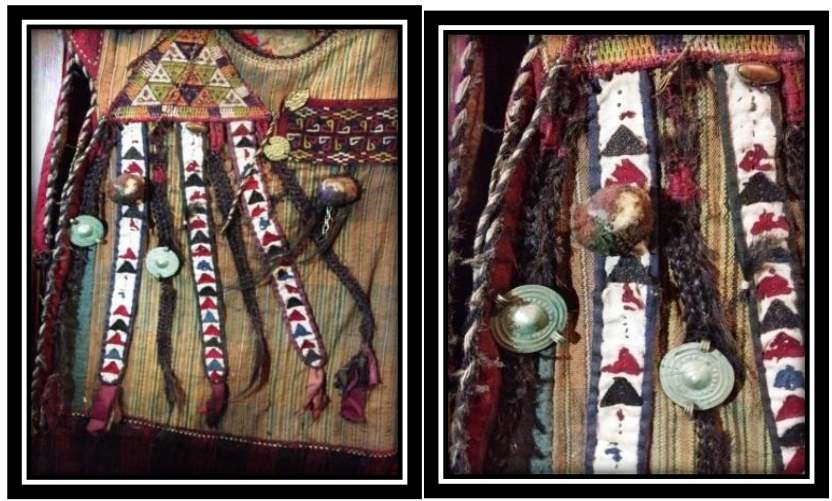

Resim 4: Resim 1'deki Çocuk Abası Detayları (Kolon Dokumalar)
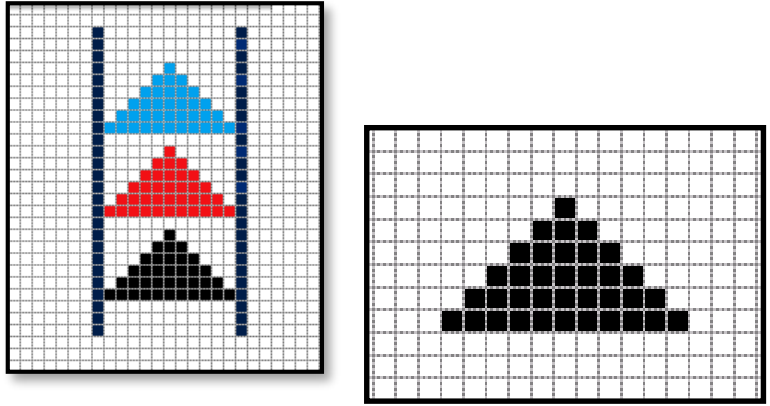

Çizim 3. Kolon Dokuma Motifi Çizim 4. Kolon Dokuma Deseni

Çizim: Z. Kırkıncıoğlu

Kolon dokumada kullanılan geometrik üçgen şekiller, stilize göz motifidir. Anadolu dokumalarında kare, eşkenar dörtgen, dikdörtgen, haç, yıldız gibi geometrik şekiller de göz motifi olarak yer almaktadır. En sık rastlanan göz motifi, dörde bölünmüş eşkenar dörtgen şeklindedir. Yörelere özgü değiş̧iklikler gösteren göz motifi dokumalarda sıklıkla koçboynuzu, eli belinde ve bereket motiflerinin etrafinda ya da içinde görülmektedir (Etikan ve Kılıçarslan, 2012: 107-105). 

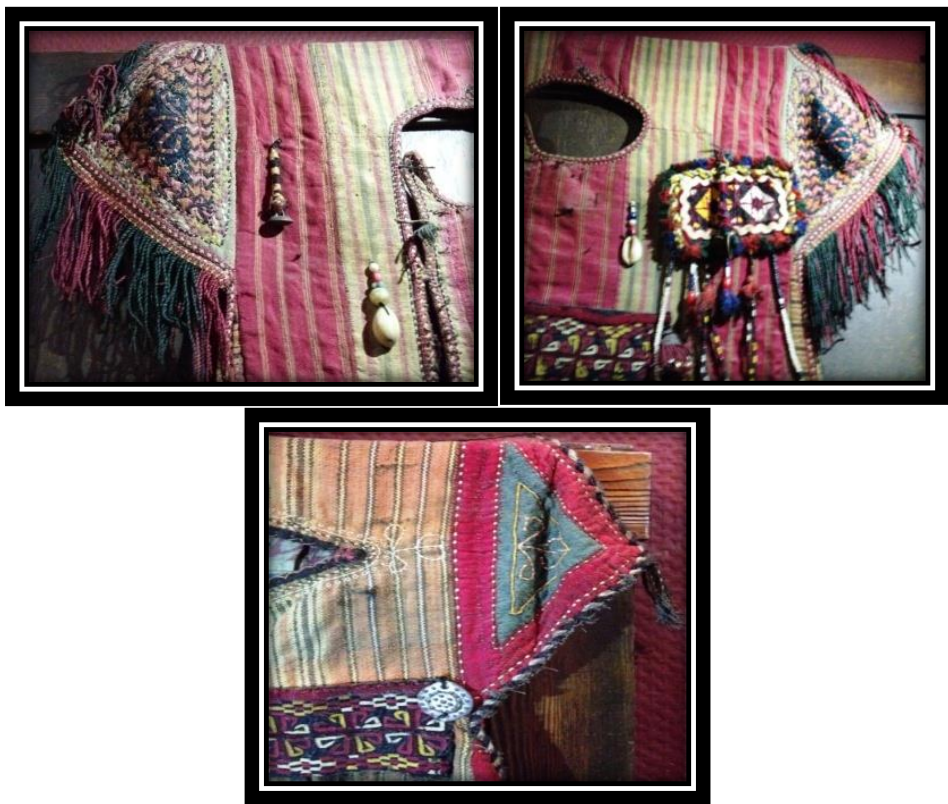

Resim5: Resim 1-2'deki Çocuk Abası Detayları (Sağ-Sol Kol)

Fotoğraf: Z. Kırkıncioğlu \& S. Kuru

Resim 5’te görülen çocuk abalarının kolları üçgen kesimli ve kol ortası yırtmaçlı çalışılmıştır. Geometrik üģgen formda yapılan kollar, muska şeklinde ve görüntüsündedir.
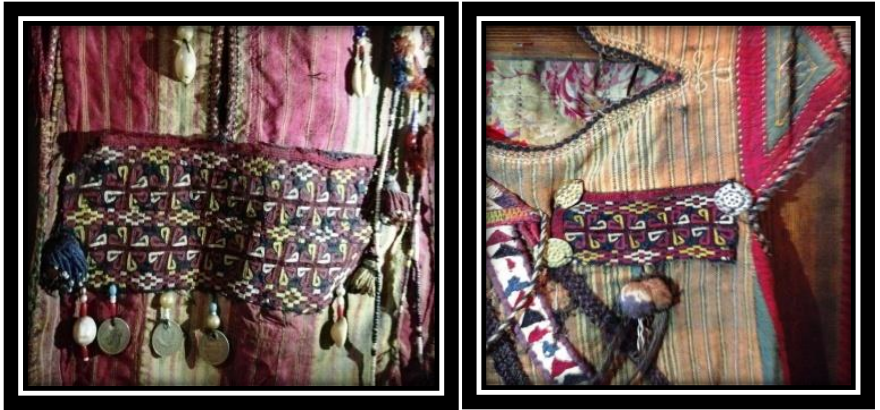

Resim 6: Resim 1-2'deki Çocuk Abası Detayları (Ön Beden) 

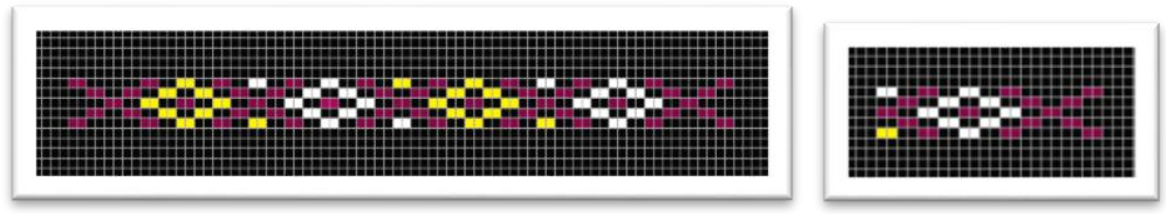

Çizim 5. Nazarlık Dokuma Motifi Çizimi 6. Kolon Dokuma Motifi Detayı
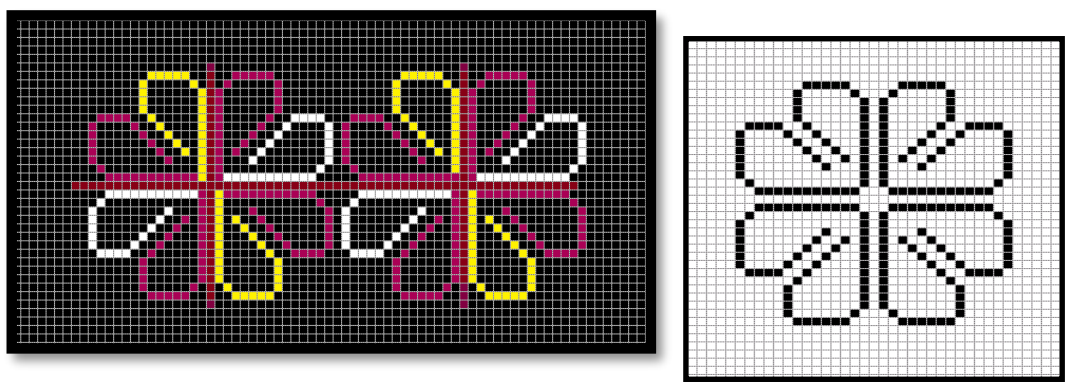

Çizim 7. Nazarlık Dokuma Motifi Çizimi 8. Nazarlık Dokuma Deseni

Çizim: Z. Kırkıncıŏglu

Geometrik formda yapılan dokumalar Resim 1'deki abada sol göğse, Resim 2'deki abada ön ortası yaka yırtmacı bitimine yerleştirilerek süslenmiştir. Bir haç ile dörde bölünmüşs şekildedir.

A ğızdan ağza, nesilden nesle yerleşen, yaşanan felaketlerin, başa gelen kötü olayların açıkça sebebi olarak görülen nazar inancının en önemli sembolü de "göz" olmuştur. Göz motifi, "göz değmek”, "nazara gelmek” şeklinde adlandırılan doğaüstü inanışları ifade etmek amacıyla, dokumalarda yaygın olarak kullanılan bir motiftir. Halk inanışına göre, göz değmeye karşı korunmanın en kolay şekli “göz”dür. Yani, kötü gözün zararlı etkisini yine ancak göz önlemektedir. Bu nedenle nazara iyi gelmesi amacıyla, dokumalarda göz motifi dokunmaktadır. Böylece, dokumaya ve dokuyucuya göz değmesi önleneceği düşünülmektedir. Göz motifi dokumalarda farklı birçok şekilde yer almaktadır. Çoğunlukla kare, üçgen ya da beşgen gibi geometrik şekillerde dokunduğu gibi bazen halk arasında, bitrak (pıtrak) diye isimlendirilen, özellikle kurak bölgelerde çok yetişen, sarmaşık türündeki bir bitkinin, dikenli meyvelerinin stilize edilmiş hali şeklinde de görülmektedir. Bazı dokumalarda da, göz motifi beş parmağ açık bir el içine gerçekçi bir şekilde yerleştirilmektedir. Geometrik şekillerden üçgen, en basite indirgenmiş stilize göz motifidir. Bununla beraber kare, eşkenar dörtgen, dikdörtgen, haç, yıldız gibi geometrik şekiller de Anadolu dokumalarında göz motifi olarak yer almaktadır (Etikan ve Kılıçarslan, 2012: 107). 
Resim 7'de gösterilen Maraş yöresine ait çocuk abası, küçük motiflerin çeşitliliğinin dokumacıların hayal gücüne ve sanatına tanıklık ettiği söylenebilir. Abanın üzerindeki dokuma nazarlığın, desenini oluşturan küçük motiflerden biri de göz motifidir. Bu dokumada yine "artı" şeklinde kenar zeminde yer almaktadır.

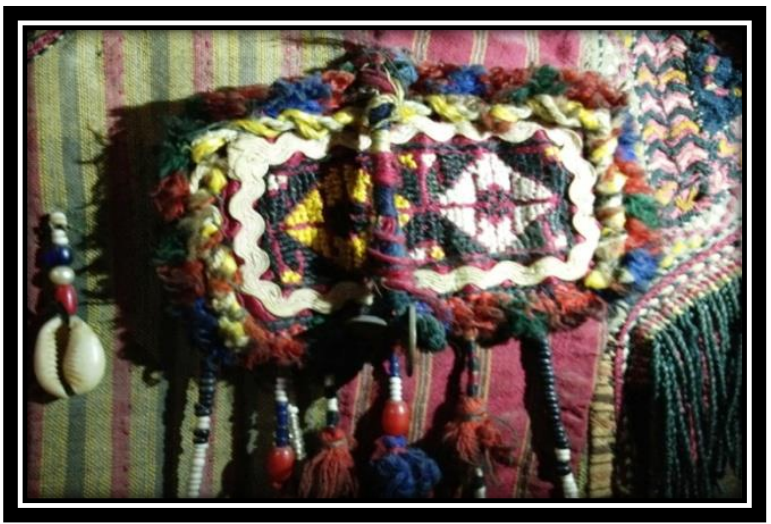

Resim 7: Resim 2'deki Çocuk Abası Detayı (Sol Göğüs Göz Motifi)
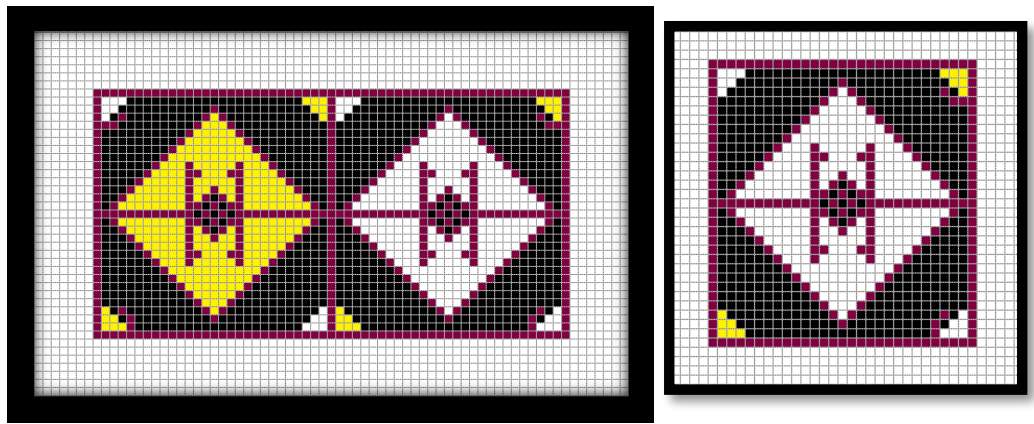

Çizim 9. Nazarlık Dokuma Motifi (Göz Motifi) Çizim 10. Nazarlık Dokuma Deseni

Çizim: Z. Kırkıncıoğlu

Nazarlık desenindeki göz motifi, kötü bakışlardan korunmak, onları uzaklaştırmak amacıyla, yörelere özgü değişiklikler göstererek eşkenar dörtgen şeklinde yer almaktadır (Resim 7). 


\section{SONUÇ}

Maddi kültürün önemli bir bölümünü geleneksel giysilerin oluşturmaktadır. Geleneksel giysilerden, kadın erkek ve çocuk giysileri şeklinde gruplandırılabilen çocuk giysilerinde yapılan süslemelerde gelenek, görenek ve inanışların etkisinin çok fazla olduğu bilinmektedir.

İnsanlar gelenek, görenek ve inanç sistemine bağl1 olarak gelişen ortak değerlerle yaşam, doğum, koruma, üreme ve benzeri ortak döngüler üzerine semboller kurgulamışlardır. Bu semboller bir arada yaşayan toplumların ortak özelliklerinin ve inançlarının diğerlerinden ayrılmasını sağlamıştır. Önceleri çok çeşitli malzemelerle koruma amaçlı yapılan bu semboller dokumanın keşfi ile birlikte desenleme tekniklerine yansıtılarak dokumalarda yapılan desen ve motiflerle anlatılmaya başlanmıştır. Dokumaların üzerine uygulanan desen ve motiflerde; doğum, çoğalma, ölüm ve korunma ile ilgili semboller kullanmışlardır.

Anadolu'nun genelinde olduğu gibi, Kahramanmaraş yöresinde de nazar inanc1 oldukça yaygındır. İnançla ilgili çeşitli korunma yöntemleri ile birlikte nazara karşı koruyucu kolonlar ve benzeri dokumalar yapmışlardır. Kahramanmaraş’ta farklı dikdörtgen, üçgen ve benzeri formlardaki dokumalar ve kolonlar ile objeler çocuk abalarının üzerinde nazara karşı koruyucu olarak çok kullanılan süslemeler olmuştur.

Kahramanmaraş çocuk abalarında nazardan korunmak için; eski paralar, mavi boncuklar, tahta ve cam boncuklar, tazı boncuğu, deniz hayvanı kabukları, sutaşı, iplikler, siyah ve renkli boncuklar, küçük kumaş parçaları, altın ve gümüş metaller, penezler, kolan ve nazar motifli dokumalar en çok kullanılanlar arasındadır. Ayrıca metal nazarlıklarda; altın ve gümüş malzeme kullanılmıştır.

Kahramanmaraş çocuk abalarında kullanılan kolon dokumalardaki geometrik üçgen şekiller, stilize göz motifidir. Bununla beraber kare, eşkenar dörtgen, baklava dilimi, dikdörtgen, haç, yıldız gibi geometrik şekiller de Anadolu dokumalarında göz motifi olarak yer almaktadır. En sık rastlanan göz motifi, dörde bölünmüş eşkenar dörtgen veya baklava dilimi şeklindedir. Göz motifi yörelere özgü değişiklikler gösterebilmektedir.

Çocuk abalarında ortası yırtmaçlı geometrik üçgen formda çalışılan kollar, muska şeklinde ve görüntüsünde olup, korunma motiflerinden olan muska ile sembolize edilmiştir. Muska, eşkenar üçgen, ikizkenar üçgen ve bazı alanlarda ise, kare, dikdörtgen, silindir şeklinde geometrik formlarda yapılarak nazardan korunmak için kullanılmaktadır.

Kahramanmaraşlı aba dokumacıların hayal gücü ve sanatına tanıklık eden çocuk abası dokumalarında kullanılan motiflerin çeşitliliği çok zarif, estetik bir şölen görümündedir. 
Abaların üzerindeki çocukları nazara karşı koruma amaçlı kullanılan kolan ve çeşitli form ve şekillerdeki dokuma nazarlıkların desenlerini oluşturan motiflerin ve bunları süsleyen çok çeşitli malzemelerinin zenginliği ise, Anadolu insanının inançları arasındaki ortak noktalarıdır.

Anadolu insanı her ne kadar hızlı bir kültürel değişimle karşı karşıya kalsa bile eski ve yeni iç içe yaşadığ 1 için, kültürü yansıtan örneklerin saklandığı görülebilmektedir.

Binlerce yıldır inanılan nazar kavramı kırsal kesimden, modern kesimlere kadar insanların somut açıklamalar getiremeyip çare aradıkları, sorumluluğu başkalarında aradıkları, gelenek ve göreneklerine sıkı sıkıya bağlı kaldıkları sürece, doğada var olduğunu kabul ettikleri inançları gibi, nazar inancından da vazgeçmeyerek ve bu anlamda nazardan korunma ve kurtulma yolundaki uygulamalarına devam edebilecekleri göz ardı edilmemelidir. 


\section{KAYNAKLAR}

ATLIHAN, Şerife. (2012). "Antalya ve Çevresinde Kolanlar", 1. Uluslararası Moda Ve Tekstil Tasarımı Sempozyumu Bildirileri, 8 Ekim-9 Kasım Antalya.

ÇIBLAK, Nilgün. (2014). "Halk Kültüründe Nazar, Nazarlık Inancı ve Bunlara Bağlı Uygulamalar", Türklük Bilimi Araştırmaları (Tübar), S.15, 103-125.

ERBERK, Mine (2002). Çatalhöyük'ten Günümüze Anadolu Motifleri, Ankara: Dumat Offset Ltd. Emek Cilt Evi.

ERTEM, BAYKAL, Figen. (2009). Dokumalarda Ve Takılarda Görülen Nazar Motifleri. Yayınlanmamış yüksek lisans tezi. Gazi Üniversitesi, Eğitim Bilimleri Enstitüsü,

ETIKAN, Sema. ve KILIÇARSLAN, Hande. (2010).“Düz Dokumalarda Nazar Inancı Ve Göz Motifi", Süleyman Demirel Üniversitesi Güzel Sanatlar Fakültesi Hakemli Dergisi Art-E, Kasım-Aralık .

KOŞAY, Hamit. Z. (1956), "Etnoğrafya Müzesinde Bulunan Nazarlık, Muska Ve Hamailler”, Türk Etnoğrafya Dergisi 1.

ÖCALAN, Fatma, Zeynep. (2010). Günümüzde Nazarlık: Formları, Kullanım Alanları Ve İşlevler, Yayınlanmamış yüksek lisans tezi. Hacettepe Üniversitesi Sosyal Bilimler Enstitüsü

ÖZTÜRK, Emine. (2005). Türk Kültüründe Nazar Ve Antalya İlinin Akseki, Alanya, Manavgat İlçelerinde Bulunan Nazarlıklar. Yayınlanmamış yüksek lisans tezi. Selçuk Üniversitesi, Sosyal Bilimler Enstitüsü.

SALMAN, Fikri. (2011). Türk Kumaş Sanatı. Erzurum: Zafer Ofset Matbaacılık Ltd. Şti.

SALMAN, Fikri ve MERCiMEK, Kevser. (2012). "Osmanlı Döneminde Maraş’ta Aba Dokumacılığı ve Günümüzde Bu Geleneği Yaşatan Bir Aba Ustası", Uluslararası Osmanlı Döneminde Maraş Sempozyumu Bildirileri. Ekim, Kahramanmaraş.

ŞAHIN, Çiğdem. (2011). Nazar-Nazarlıkla Ilgili Inanışlar, Uygulamalar Ve Bunların Dini- Mitolojik Kökenleri (Gaziantep Yöresi),Yayınlanmamış yüksek lisans tezi. Gaziantep Üniversitesi, Sosyal Bilimler Enstitüsü.

ÜÇER, Müjgan. (1997). "Sivas Yöresinde Nazarlıklar ve Nazarla ilgili İnançlar", V. Milletlerarası Türk Halk Kültürü Kongresi Gelenek Görenek Inançlar Seksiyon Bildirileri, Kültür Bakanlığı.

YILDIRIM, Leyla. (2006). "Geleneksel Sanattan Günümüz Tekstil Sanatına Sembolizm Olgusunun Değişimi", Uluslararası Geleneksel Sanatlar Sempozyumu Bildirileri, Dokuz Eylül Üniversitesi Güzel Sanatlar Fakültesi Geleneksel Türk El Sanatları Bölümü, Cilt: 1. 
